\title{
Deer antler extract potentially facilitates xiphoid cartilage growth and regeneration and prevents inflammatory susceptibility by regulating multiple functional genes
}

\author{
Mengqi Guan ${ }^{1 \dagger}$, Daian Pan ${ }^{2 \dagger}$, Mei Zhang ${ }^{3}$, Xiangyang Leng ${ }^{1 *}$ and Baojin Yao ${ }^{2^{*}}$ (D)
}

\begin{abstract}
Background: Deer antler is a zoological exception due to its fantastic characteristics, including amazing growth rate and repeatable regeneration. Deer antler has been used as a key ingredient in traditional Chinese medicine relating to kidney and bone health for centuries. The aim of this study was to dissect the molecular regulation of deer antler extract (DAE) on xiphoid cartilage (XC).

Methods: The DAE used in this experiment was same as the one that was prepared as previously described. The specific pathogen-free (SPF) grade Sprague-Dawley (SD) rats were randomly divided into blank group $(n=10)$ and DAE group $(n=10)$ after 1-week adaptive feeding. The DAE used in this experiment was same as the one that was prepared as previously described. The rats in DAE group were fed with DAE for 3 weeks at a dose of $0.2 \mathrm{~g} / \mathrm{kg}$ per day according to the body surface area normalization method, and the rats in blank group were fed with drinking water. Total RNA was extracted from XC located in the most distal edge of the sternum. Illumina RNA sequencing (RNA-seq) in combination with quantitative real-time polymerase chain reaction (qRT-PCR) validation assay was carried out to dissect the molecular regulation of DAE on XC.
\end{abstract}

Results: We demonstrated that DAE significantly increased the expression levels of DEGs involved in cartilage growth and regeneration, but decreased the expression levels of DEGs involved in inflammation, and mildly increased the expression levels of DEGs involved in chondrogenesis and chondrocyte proliferation.

Conclusions: Our findings suggest that DAE might serve as a complementary therapeutic regent for cartilage growth and regeneration to treat cartilage degenerative disease, such as osteoarthritis.

Keywords: Deer antler extract, Xiphoid cartilage, RNA sequencing, Molecular regulation, Growth, Regeneration

\footnotetext{
*Correspondence: leng_xiangyang@163.com; ybj19830928@sina.com

${ }^{\dagger}$ Mengqi Guan and Daian Pan contributed equally to this work.

'College of Traditional Chinese Medicine, Changchun University of Chinese

Medicine, Changchun 130117, China

${ }^{2} \mathrm{Jilin}$ Ginseng Academy, Changchun University of Chinese Medicine,

Changchun 130117, China

Full list of author information is available at the end of the article
}

(c) The Author(s). 2021 Open Access This article is licensed under a Creative Commons Attribution 4.0 International License, which permits use, sharing, adaptation, distribution and reproduction in any medium or format, as long as you give appropriate credit to the original author(s) and the source, provide a link to the Creative Commons licence, and indicate if changes were made. The images or other third party material in this article are included in the article's Creative Commons licence, unless indicated otherwise in a credit line to the material. If material is not included in the article's Creative Commons licence and your intended use is not permitted by statutory regulation or exceeds the permitted use, you will need to obtain permission directly from the copyright holder. To view a copy of this licence, visit http://creativecommons.org/licenses/by/4.0/ The Creative Commons Public Domain Dedication waiver (http://creativecommons.org/publicdomain/zero/1.0/) applies to the data made available in this article, unless otherwise stated in a credit line to the data. 


\section{Background}

Xiphoid cartilage (XC), also known as xiphoid process, is a small cartilaginous region located in the lower part of the sternum [1]. The major function of $\mathrm{XC}$ is to serve as an attachment for soft tissues and helps protect the internal thoracic viscera, such as the heart and lungs [2]. Although the $\mathrm{XC}$ is hided in the infrasternal angle, it is still vulnerable to be broken, usually caused by a chest trauma, and results in chest or abdominal pain, termed xiphodynia or xiphoidalgia [3]. The major cause for the pain syndrome is due to the injury in the XC region accompanied with inflammation [4]. Since cartilage is solely composed of cells, namely, chondrocytes, which have very poor capacities for self-renewal, cartilage regeneration remains one of the major challenges in this century [5].

Deer antler is a zoological exception due to its fantastic characteristics, including amazing growth rate and repeatable regeneration [6]. The maximal growth rate during antler growth can reach to $2 \mathrm{~cm}$ per day, representing the fastest growth rate of tissue growth among mammalian species [7]. Antler growth is powered by the proliferation and differentiation of cells resided in the antler tip, known as antler growth center, which is a cartilaginous structure classified into different zones, such as mesenchyme, precartilage, cartilage, and mineralized cartilage, and the process of antler growth resembles that of endochondral ossification during long bone development $[8,9]$. Deer antler has been used as a key ingredient in traditional Chinese medicine relating to kidney and bone health for centuries [10]. However, the regulation of deer antler on cartilage homeostasis and development remains largely unknown.

In recent years, our group has carried out a series of studies for the purpose of getting insight into the molecular control of deer antler on the regulation of chondrocytes. Our findings indicate that the major active components in deer antler are aqueous proteins, which account for $70 \%$ of the freshly prepared aqueous extract (DAE) [11]. Furthermore, DAE dramatically facilitate chondrocyte viability and hold chondrocytes in a continuously proliferative state, while prevent chondrocytes from further maturation, differentiation, and apoptosis $[11,12]$. In the present study, we treated rats with DAE, and analyzed the gene expression profiles of xiphoid cartilage by using RNA sequencing (RNA-seq) technology in combination with quantitative real-time polymerase chain reaction (qRT-PCR) verification method to uncover the molecular control of DAE on cartilage regulation. We demonstrated that DAE significantly increased the expression levels of DEGs involved in cartilage growth and regeneration, but decreased the expression levels of DEGs involved in inflammation, and mildly increased the expression levels of DEGs involved in chondrogenesis and chondrocyte proliferation.

\section{Methods \\ Experimental animals and treatment}

The specific pathogen-free (SPF) grade Sprague-Dawley (SD) rats at the age of 7-week old were purchased from the Changchun Yisi Laboratory Animal Technology Co., Ltd. (Changchun, China) with the permission number SCXK (Ji) 2016-0003. The rats were housed in an air conditioned and light/dark (12/12 h) cycled room, with the temperature range from 23 to $25{ }^{\circ} \mathrm{C}$ in combination with a relative humidity of $50 \%$ and free access to food and water. The animal protocol was approved by the Institutional Animal Care and Use Committee of Changchun University of Chinese Medicine and all experimental procedures were performed in accordance with corresponding standards and guidelines. After 1-week adaptive feeding, the rats were randomly divided into two groups: blank group $(n=10)$ and DAE group $(n=10)$. The DAE used in this experiment was same as the one that was prepared as previously described [11], and the administration was carried out as previously described [13]. Briefly, the rats in DAE group were fed with DAE for 3 weeks at a dose of $0.2 \mathrm{~g} / \mathrm{kg}$ per day according to the body surface area normalization method [14], and the rats in blank group were fed with drinking water.

\section{Tissue collection and RNA isolation}

After 3-week DAE administration, all rats were killed by carbon dioxide euthanasia and cervical dislocation. Xiphoid cartilage from each rat was carefully removed from the most distal edge of the sternum with a scalpel blade. The samples from each group were pooled together separately, and grinded it to fine powders using a pestle and mortar with liquid nitrogen. Total RNA from each group was extracted from the cartilage tissues with the TRIzol reagent (Invitrogen, USA) in accordance with the company's protocols. RNA quality was assessed using an Agilent 2100 Bioanalyzer (Agilent Technologies, USA).

\section{Library preparation and Illumina sequencing}

Library construction was prepared with the TruSeq Stranded mRNA kit (Illumina, USA) in accordance with the manufacturer's recommendations. Briefly, mRNA was purified, fragmented, and reverse transcribed into double-stranded cDNA followed by end repair and adapter ligation. The generated fragments were further selectively amplified by polymerase chain reaction (PCR) to generate the libraries. Transcriptome sequencing was performed on an Illumina HiSeq 2500 platform (Illumina, USA) with a paired-end read of $150 \mathrm{bp}$ in length. 


\section{Data analysis}

The raw reads were filtered via perl scripts to yield highquality clean reads by excluding the adapter sequences, eliminating the unknown nucleotides and removing the low-quality reads. The clean reads were aligned to the rat (Rattus norvegicus) genome via HISAT [15], and gene expression levels were quantified with the FPKM method [16]. Differentially expressed genes (DEGs) were detected using the DEGseq method [17]. Genes with a $\log _{2}$ fold change $\geq 1$ or $\leq-1$ and a $p$ value $\leq 0.001$ were defined as significantly differentially expressed. Enrichment analysis was further carried out by mapping the DEGs into Gene ontology (GO) and Kyoto Encyclopedia of Genes and Genomes (KEGG) databases using an R function phyper accompanied with multiple testing corrections. GO terms or KEGG pathways with an adjusted $p$ value ( $Q$ value) less than 0.05 were regarded as significantly enriched [18].

\section{Validation by qRT-PCR assay}

Gene expression levels of selected DEGs from RNA-seq analysis were validated by qRT-PCR assay. Briefly, total RNA used for RNA-seq was used as a template for cDNA synthesis via the iScript cDNA Synthesis Kit (BioRad, USA) and subsequently amplified on the CFX Connect Real-Time PCR Detection System (Bio-Rad, USA) by using the SsoAdvanced Universal SYBR ${ }^{\circ}$ Green Supermix (Bio-Rad, USA) in accordance with the manufacturer's instructions. The relative mRNA expression levels were calculated according to the $2^{-\Delta \Delta C T}$ algorithm, and the rat glyceraldehyde 3-phosphate dehydrogenase gene (Gapdh) was applied as a reference gene for normalization [19].

\section{Results}

\section{Statistics summary of transcriptome sequencing and} assembly

All of the raw reads from xiphoid cartilage samples of rats with or without the treatment of DAE were deposited into the NCBI Sequence Read Archive (SRA) database with a BioProject accession number PRJNA611513. As shown in Table 1, after removing adaptors and lowquality reads, a total of 45,373,826 (blank group) and 41,

Table 1 Statistics summary of transcriptome sequencing and assembly

\begin{tabular}{lll}
\hline Statistics & Blank & DAE \\
\hline Clean reads & $45,373,826$ & $41,652,368$ \\
Q30 percentage & 91.17 & 91.60 \\
GC percentage & 51.94 & 52.90 \\
Total mapped reads & $41,077,322$ & $37,894,242$ \\
Total transcripts & 15,275 & 14,970 \\
Known transcripts & 12,632 & 12,323 \\
\hline
\end{tabular}

652,368 (DAE group) clean reads were obtained in each of the profiles, respectively. The quality control results showed that the Q30 value was above 91\%, and the GC content was around $52 \sim 53 \%$ in each group, indicating high accuracy and reliability of the RNA-seq data. Among the clean reads, approximately 41 million (blank group) and 38 million (DAE group) reads were mapped to the rat (Rattus norvegicus) genome, subsequently, 12, 632 out of 15,275 (blank group) and 12,323 out of 14, 970 (DAE group) known transcripts were identified by searching against the NCBI non-redundant (NR) protein database and Swiss-Prot database, respectively.

Differential expression and functional enrichment analysis In total, 892 DEGs were identified between the blank group and the DAE group, with 181 significantly upregulated genes and 711 significantly downregulated genes by comparing the blank group and DAE group based on the following criteria: $\log _{2}$ fold change $\geq 1$ or $\leq-1$ and $p$ $\leq 0.001$, as shown in Table 2 . GO enrichment analysis was performed to identify the biological importance of DEGs under DAE treatment, as shown in Fig. 1. In the cellular component category, the DEGs were predominantly located in the organelle, vesicle, and exosome regions. In the molecular function category, the DEGs were mainly involved in the binding and catalytic activities. In the biological process category, the DEGs primarily participated in the metabolic and developmental processes. KEGG pathway enrichment analysis was performed to further determine the biological pathways in which these DEGs may be participated, as shown in Fig. 2. The DEGs were predominantly mapped to the following pathways, including tight junction, PPAR, platelet activation, focal adhesion, complement and coagulation cascades, and AMPK.

\section{DAE remarkably promote the expression levels of DEGs} participated in cartilage growth and regeneration

Among the significantly upregulated DEGs, 17 DEGs participated in cartilage growth and regeneration were pointed out, including connective tissue growth factor (Ctgf), fibronectin (Fn1), aggrecan core protein (Acan), lysyl oxidase homolog 4 (Loxl4), protein CYR61 (Cyr61), sestrin-3 (Sesn3), proteoglycan 4 (Prg4), filamin-B (Flnb), frizzled-7 (Fzd7), bone morphogenetic protein 7 (Bmp7), bone morphogenetic protein 6 (Bmp6), golgin subfamily B member 1 (Golgb1), peptidase inhibitor 15 (Pi15),

Table 2 Statistic overview of DEGs (DAE vs. blank)

\begin{tabular}{ll}
\hline Statistics & Number \\
\hline Differentially expressed mRNAs & 892 \\
Upregulated mRNAs & 181 \\
Downregulated mRNAs & 711 \\
\hline
\end{tabular}




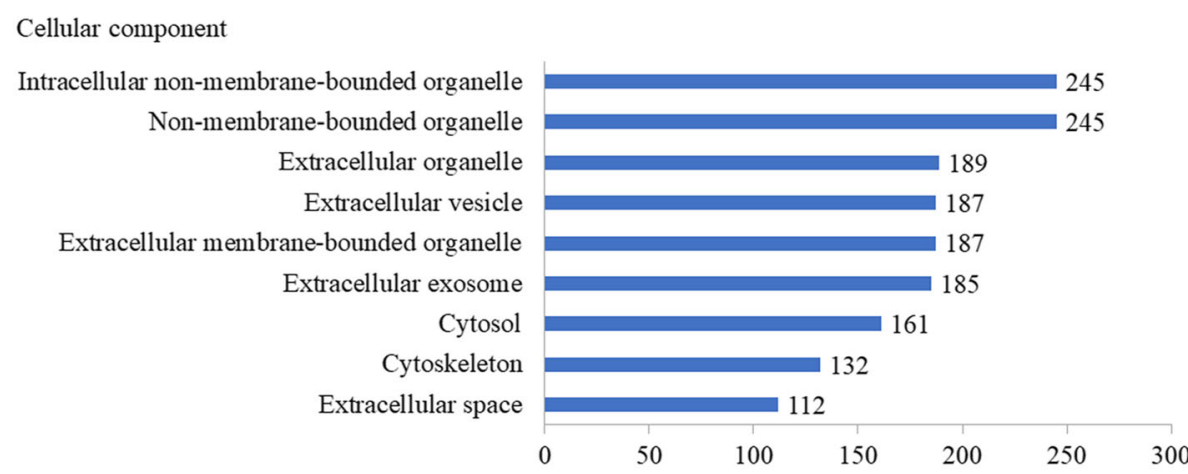

Molecular function

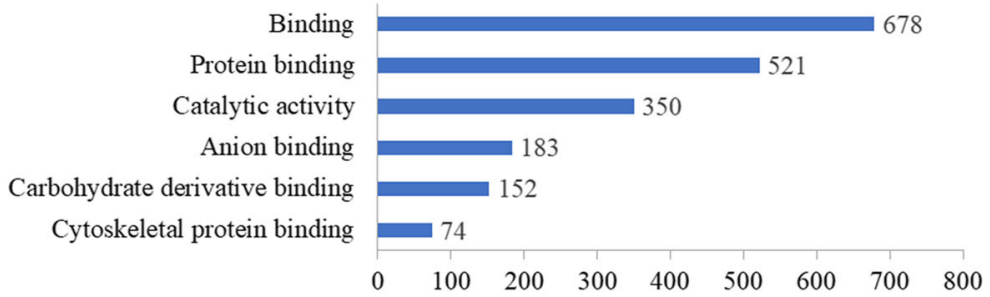

Biological process

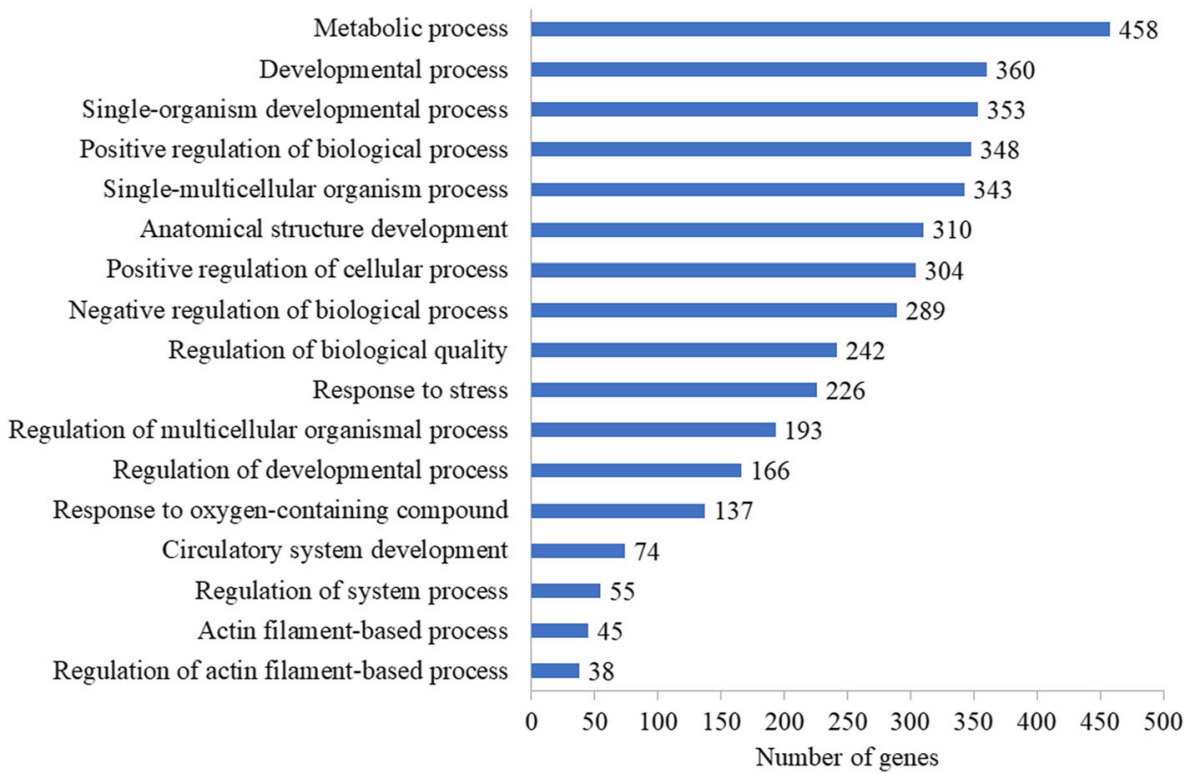

Fig. $1 \mathrm{GO}$ enrichment analysis of XC under DAE treatment. The $x$-axis indicates the number of mapped genes in a category, and the $x$-axis indicates the significantly enriched $\mathrm{GO}$ terms $(p<0.05)$ in different categories including cellular component, molecular function, and biological process

krueppel-like factor 9 (Klf9), zinc finger protein GLI2 (Gli2), ephrin-A5 (Efna5), and zinc finger transcription factor Trps1(Trps1), as shown in Table 3.

\section{DAE remarkably suppressed the expression levels of DEGs participated in inflammation}

Among the significantly upregulated DEGs, 30 DEGs participated in inflammation were recognized, including 40S ribosomal protein S24 (Rps24), fatty acid-binding protein (Fabp4), beta-2-microglobulin (B2m), mimecan (Ogn), retinoid-binding protein 7 (Rbp7), lysozyme C-1 (Lyz1), adiponectin (Adipoq), CCAAT/enhancer-binding protein delta (Cebpd), thyroid hormone-inducible hepatic protein (Thrsp), DnaJ homolog subfamily $\mathrm{C}$ member 15 (Dnajc15), CCAAT/enhancer-binding protein beta (Cebpb), platelet glycoprotein $4(\mathrm{Cd} 36)$, resistin (Retn), collagen alpha-1(IV) chain (Col4a1), and angiotensinogen (Agt), as shown in Table 4. 


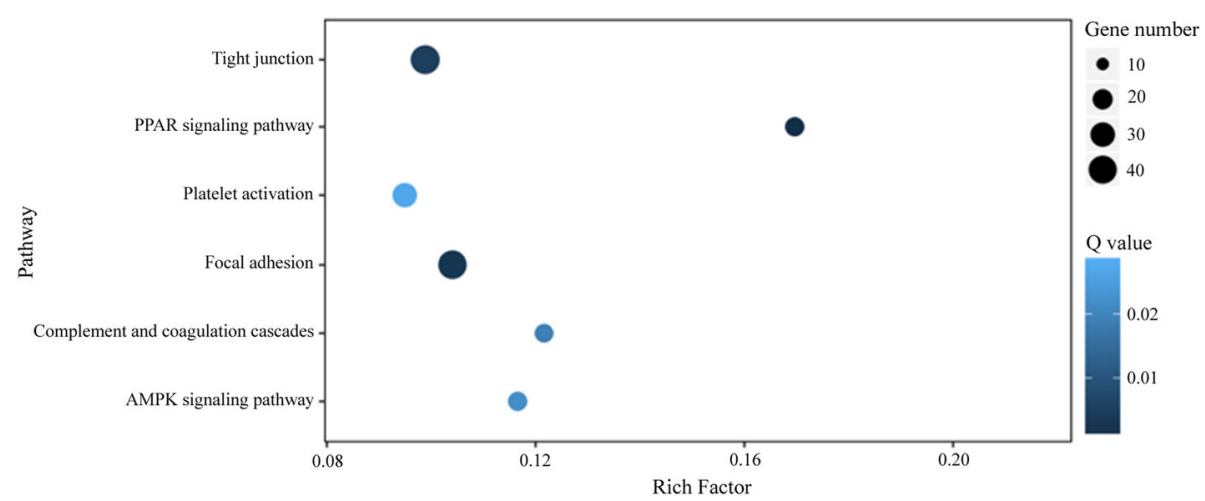

Fig. 2 KEGG enrichment analysis of XC under DAE treatment. The $x$-axis indicates the rich factor that is presented by the ratio of DEG number in the total gene number of a defined pathway, and the $x$-axis indicates the name of enriched pathway. The color of the dots represents the range of the $Q$ value, and the size of the dots represents the number of DEGs mapped to a defined pathway, respectively

DAE mildly increased the expression levels of DEGs participated in chondrogenesis and chondrocyte proliferation

In order to deeply investigate the effects of DAE on xiphoid cartilage, we further analyzed the expression patterns of genes participated in chondrogenesis and chondrocyte proliferation. According to the RNA-seq analysis, the expression levels of 8 chondroprogenitor markers including collagen alpha-1(II) chain (Col2a1), aggrecan core protein (Acan), hyaluronan and proteoglycan link protein 1 (Hapln1), collagen alpha1(IX) chain (Col9a1), collagen alpha-1(XI) chain (Col11a1), transcription factor SOX-9 (Sox9), transcription factor SOX-6 (Sox6), and transcription factor SOX5 (Sox5), and 5 proliferative chondrocyte markers including cartilage oligomeric matrix protein (Comp), fibroblast growth factor receptor 3 (Fgfr3), cartilage matrix protein (Matn1), syndecan-3 (Sdc3), and protein patched homolog 1 (Ptch1) were mildly increased under DAE treatment, as shown in Table 5.

Table 3 Comparison of gene expression patterns of DEGs participated in cartilage growth and regeneration

\begin{tabular}{|c|c|c|c|c|}
\hline \multirow[t]{2}{*}{ Gene name } & \multicolumn{2}{|c|}{ Expression level (FPKM) } & \multirow{2}{*}{$\begin{array}{l}\log _{2} \\
\text { fold } \\
\text { change } \\
\text { (DAE/ } \\
\text { blank) }\end{array}$} & \multirow[t]{2}{*}{$p$ value } \\
\hline & Blank & DAE & & \\
\hline Connective tissue growth factor (Ctgf) & 1071.72 & 2155.72 & 1.01 & 0 \\
\hline Fibronectin (Fn1) & 703.09 & 1775.29 & 1.34 & 0 \\
\hline Aggrecan core protein (Acan) & 694.33 & 1466.54 & 1.08 & 0 \\
\hline Lysyl oxidase homolog 4 (Lox|4) & 88.25 & 191.04 & 1.11 & 0 \\
\hline Protein CYR61 (Cyr61) & 29.43 & 60.45 & 1.04 & $3.52 \mathrm{E}-44$ \\
\hline Sestrin-3 (Sesn3) & 16.14 & 33.95 & 1.07 & $2.12 \mathrm{E}-39$ \\
\hline Proteoglycan 4 (Prg4) & 15.12 & 31.45 & 1.06 & $1.02 \mathrm{E}-49$ \\
\hline Filamin-B (FInb) & 12.00 & 30.41 & 1.34 & $1.68 \mathrm{E}-151$ \\
\hline Frizzled-7 (Fzd7) & 6.71 & 14.64 & 1.13 & 1.47E-18 \\
\hline Bone morphogenetic protein 7 (Bmp7) & 4.83 & 14.31 & 1.57 & 1.97E-25 \\
\hline Bone morphogenetic protein 6 (Bmp6) & 6.80 & 13.61 & 1.00 & $2.85 \mathrm{E}-08$ \\
\hline Golgin subfamily B member 1 (Golgb1) & 4.44 & 10.82 & 1.29 & 4.13E-64 \\
\hline Peptidase inhibitor 15 (Pi15) & 3.14 & 9.50 & 1.60 & 4.44E-10 \\
\hline Krueppel-like factor 9 (Klf9) & 4.24 & 9.49 & 1.16 & $9.91 \mathrm{E}-13$ \\
\hline Zinc finger protein GLI2 (Gli2) & 4.02 & 8.50 & 1.08 & $1.48 \mathrm{E}-24$ \\
\hline Ephrin-A5 (Efna5) & 4.05 & 8.39 & 1.05 & 7.06E-11 \\
\hline Zinc finger transcription factor $\operatorname{Trps} 1$ (Trps1) & 1.56 & 3.72 & 1.25 & $1.98 \mathrm{E}-15$ \\
\hline
\end{tabular}


Table 4 Comparison of gene expression patterns of DEGs participated in inflammation

\begin{tabular}{|c|c|c|c|c|}
\hline \multirow[t]{2}{*}{ Gene name } & \multicolumn{2}{|c|}{ Expression level (FPKM) } & \multirow{2}{*}{$\begin{array}{l}\log _{2} \text { fold } \\
\text { change } \\
\text { (DAE/ } \\
\text { blank) }\end{array}$} & \multirow[t]{2}{*}{$p$ value } \\
\hline & Blank & DAE & & \\
\hline 40 S ribosomal protein S24 (Rps24) & 4192.80 & 2010.43 & -1.06 & 0 \\
\hline Fatty acid-binding protein (Fabp4) & 2432.08 & 468.50 & -2.38 & 0 \\
\hline Beta-2-microglobulin (B2m) & 516.35 & 237.92 & -1.12 & 0 \\
\hline Osteoglycin (Ogn) & 140.89 & 67.67 & -1.06 & $2.91 \mathrm{E}-46$ \\
\hline Retinoid-binding protein 7 (Rbp7) & 253.48 & 65.29 & -1.96 & 4.24E-116 \\
\hline Lysozyme C-1 (Lyz1) & 120.53 & 55.53 & -1.12 & $6.30 \mathrm{E}-56$ \\
\hline Adiponectin (Adipoq) & 293.37 & 45.45 & -2.69 & 0 \\
\hline CCAAT/enhancer-binding protein delta (Cebpd) & 80.67 & 38.92 & -1.05 & $5.26 \mathrm{E}-32$ \\
\hline Thyroid hormone-inducible hepatic protein (Thrsp) & 221.82 & 36.82 & -2.59 & 0 \\
\hline DnaJ homolog subfamily C member 15 (Dnajc15) & 70.79 & 34.30 & -1.05 & $2.10 \mathrm{E}-18$ \\
\hline CCAAT/enhancer-binding protein beta (Cebpb) & 70.21 & 32.67 & -1.10 & $5.94 \mathrm{E}-40$ \\
\hline Platelet glycoprotein 4 (Cd36) & 112.80 & 27.68 & -2.03 & 4.07E-293 \\
\hline Resistin (Retn) & 144.77 & 25.36 & -2.51 & 2.83E-84 \\
\hline Collagen alpha-1(IV) chain (Col4a1) & 43.97 & 18.93 & -1.22 & $3.28 \mathrm{E}-137$ \\
\hline Angiotensinogen (Agt) & 63.79 & 18.67 & -1.77 & $9.28 \mathrm{E}-99$ \\
\hline O-acetyl-ADP-ribose deacetylase MACROD1 (Fragment) (Macrod1) & 38.50 & 16.56 & -1.22 & $6.04 \mathrm{E}-18$ \\
\hline Interferon alpha-inducible protein 27-like protein 2B (Ifi27l2b) & 46.39 & 16.54 & -1.49 & $8.20 E-11$ \\
\hline NF-kappa-B inhibitor alpha (Nfkbia) & 38.08 & 16.10 & -1.24 & $8.49 \mathrm{E}-29$ \\
\hline Complement C1q subcomponent subunit C (C1qc) & 29.82 & 14.74 & -1.02 & 2.57E-11 \\
\hline CCAAT/enhancer-binding protein alpha (Cebpa) & 39.76 & 12.49 & -1.67 & $2.30 \mathrm{E}-79$ \\
\hline Stromal cell-derived factor 1 (Cxcl12) & 23.58 & 11.21 & -1.07 & $2.72 \mathrm{E}-21$ \\
\hline C-C motif chemokine 21a (Ccl21a) & 64.52 & 9.09 & -2.83 & $6.67 \mathrm{E}-71$ \\
\hline C-X-C motif chemokine 13 (Cxcl13) & 30.87 & 8.38 & -1.88 & $1.49 \mathrm{E}-28$ \\
\hline Sorting nexin-2 (Sn×2) & 15.47 & 6.35 & -1.28 & $5.23 \mathrm{E}-17$ \\
\hline Cathepsin S (Ctss) & 12.32 & 5.89 & -1.06 & $3.23 \mathrm{E}-07$ \\
\hline Complement C1q subcomponent subunit B (C1qb) & 13.93 & 5.73 & -1.28 & $1.13 \mathrm{E}-08$ \\
\hline Matrix metalloproteinase-23 (Mmp23) & 15.41 & 5.72 & -1.43 & $1.68 \mathrm{E}-12$ \\
\hline Spondin-2 (Spon2) & 13.07 & 5.71 & -1.19 & $2.15 \mathrm{E}-11$ \\
\hline Leucine-rich alpha-2-glycoprotein (Lrg1) & 12.31 & 5.55 & -1.15 & 7.57E-08 \\
\hline Peroxidasin homolog (Pxdn) & 12.59 & 5.36 & -1.23 & $3.23 \mathrm{E}-41$ \\
\hline
\end{tabular}

The results of DEGs verified by qRT-PCR were consistent with those of RNA-seq analysis

Gene expression levels of 30 DEGs were verified by qRT-PCR method to corroborate the accuracy and reliability of the RNA-seq results, including 10 upregulated DGEs (Ctgf, Fn1, Acan, Loxl4, Cyr61, Sesn3, Prg4, Flnb, Fzd7, and Bmp7) involved in cartilage growth and regeneration, 10 downregulated DEGs (Rps24, Fabp4, B2m, Ogn, Rbp7, Lyzl1, Adipoq, Cebpd, Thrsp, and Dnajc15) involved in inflammation, and 10 genes (Col2a1, Acan, Hapln1, Col9a1, Col11a1, Sox9, Sox6, Sox5, Comp, and Fgfr3) involved in chondrogenesis and chondrocyte proliferation. The forward and reverse primer sequences for
qRT-PCR were listed in Table 6. The relative fold change in gene expression of each gene was normalized to the internal control gene Gapdh. As shown in Fig. 3, the expression patterns of these 30 genes were consistent with the results of the RNA-seq analysis.

\section{Discussion}

Cartilage is a specialized tissue that does not have nerves, blood vessels, or lymphatics, and has poor selfhealing capacity after degeneration or injury, subsequently cause degenerative diseases, such as osteoarthritis, which affected more than 300 million people globally in 2017. Thus, cartilage regeneration currently is 
Table 5 Comparison of gene expression patterns of identified genes participated in chondrogenesis and chondrocyte proliferation

\begin{tabular}{|c|c|c|c|c|}
\hline \multirow[t]{2}{*}{ Gene name } & \multicolumn{2}{|c|}{ Expression level (FPKM) } & \multirow{2}{*}{$\begin{array}{l}\log _{2} \\
\text { fold } \\
\text { change } \\
\text { (DAE/ } \\
\text { blank) }\end{array}$} & \multirow[t]{2}{*}{$p$ value } \\
\hline & Blank & DAE & & \\
\hline \multicolumn{5}{|l|}{ Chondroprogenitor markers } \\
\hline Collagen alpha-1(II) chain (Col2a1) & 3233.52 & 6358.59 & 0.98 & 0 \\
\hline Aggrecan core protein (Acan) & 694.33 & 1466.54 & 1.08 & 0 \\
\hline Hyaluronan and proteoglycan link protein 1 (Hapln1) & 227.28 & 349.36 & 0.62 & $2.72 \mathrm{E}-114$ \\
\hline Collagen alpha-1(IX) chain (Col9a1) & 177.51 & 313.96 & 0.82 & 7.21E-297 \\
\hline Collagen alpha-1(XI) chain (Col11a1) & 130.70 & 245.99 & 0.91 & 0 \\
\hline Transcription factor SOX-9 (Sox9) & 36.03 & 64.54 & 0.84 & $2.50 \mathrm{E}-68$ \\
\hline Transcription factor SOX-6 (Sox6) & 5.21 & 7.61 & 0.55 & $3.88 \mathrm{E}-05$ \\
\hline Transcription factor SOX-5 (Sox5) & 3.62 & 5.42 & 0.58 & $1.93 \mathrm{E}-06$ \\
\hline \multicolumn{5}{|l|}{ Proliferative chondrocyte markers } \\
\hline Cartilage oligomeric matrix protein (Comp) & 1143.78 & 1839.31 & 0.69 & 0 \\
\hline Fibroblast growth factor receptor 3 (Fgfr3) & 227.52 & 266.94 & 0.23 & $5.04 \mathrm{E}-24$ \\
\hline Cartilage matrix protein (Matn1) & 148.54 & 253.96 & 0.77 & 1.19E-105 \\
\hline Syndecan-3 (Sdc3) & 25.24 & 32.91 & 0.38 & $1.39 \mathrm{E}-11$ \\
\hline Protein patched homolog 1 (Ptch1) & 3.94 & 6.14 & 0.64 & $5.10 \mathrm{E}-06$ \\
\hline
\end{tabular}

still a worldwide challenge [20,21]. Among the different types of cartilage, $\mathrm{XC}$ can be obtained conveniently, and has a potential capacity for cartilage reconstruction due to its expansion and differentiation characteristics, and it has been widely used as a tissue model for investigation cartilage injury and repair [22-24]. Furthermore, it has been shown that XC contains cartilaginous tissue with a similar histological structure to that of articular cartilage, and histological and metabolic changes in murine XC are similar to those in articular cartilage after mechanical injury [25]. Deer antler serves as not only a unique model for studying cartilage regeneration and rapid growth but also a well-known traditional Chinese medicine for cartilage and bone enhancement. Our group previously demonstrated that the major active components in deer antler are aqueous proteins, which account for $70 \%$ of the freshly prepared aqueous extract (DAE). DAE dramatically facilitate chondrocyte viability and hold chondrocytes in a continuously proliferative state, while prevent chondrocytes from further maturation, differentiation, and apoptosis $[11,12]$. Thus, the discovery of the regulation effect of deer antler on xiphoid cartilage would be a great benefit for finding complementary therapy to prevent or treat cartilagerelated disease.

Based on the RNA-seq analysis, 892 genes were identified as DEGs, including 181 significantly upregulated genes and 711 significantly downregulated genes by comparing the blank group and DAE group. According to the GO enrichment analysis, the majority of the DEGs were primarily participated in the metabolic and developmental processes with binding and catalytic activities. These findings suggest that DAE potentially induce XC metabolic and developmental changes. According to the KEGG pathway enrichment analysis, the majority of the DEGs were mainly mapped to tight junction, PPAR, platelet activation, focal adhesion, complement and coagulation cascades, and AMPK signaling pathways. Among these enriched signaling pathways, tight junction functions as a paracellular gate to maintain organ or tissue homoeostasis by controlling diffusion on the basis of size and charge [26]. PPAR signaling consists of a group of nuclear receptor proteins, which functions as transcription factors to regulate cartilage growth and development [27]. Platelet activation serves as a key process during cartilage repair, since injured cartilage with platelet activation presents better chondral cellularity and regeneration [28]. Focal adhesion is the contact point that attaches chondrocytes to the pericellular cartilage matrix and links to intracellular organelles via cytoskeleton, and is involved in multiple cellular activities such as migration, proliferation, and gene expression [29]. Complement and coagulation cascade serves as a mediator of innate immunity, and play pivotal roles during cartilage physiological and pathological processes [30]. AMPK is a serine/threonine kinase that constitutively present in normal articular chondrocytes, and AMPK deficiency is associated with chondrocyte senescence and related diseases, such as osteoarthritis [31]. These findings suggest that DAE potentially secure XC 
Table 6 List of genes and their specific primer sequences for qRT-PCR validation

\begin{tabular}{|c|c|c|}
\hline Gene name & Primer & Sequence \\
\hline \multirow[t]{2}{*}{ Ctgf } & Forward primer & CGAAGTGAGAACCGTGTGTC \\
\hline & Reverse primer & CTGGCATCTCCACTCTTCCA \\
\hline \multirow[t]{2}{*}{ Fn1 } & Forward primer & AATGGTGACAGTTGGTTGCC \\
\hline & Reverse primer & CATTGCATCGTGGTTGGCTA \\
\hline \multirow[t]{2}{*}{ Acan } & Forward primer & GCTACCCTGATCCCTCATCC \\
\hline & Reverse primer & GATGTCCTCTTCACCACCCA \\
\hline \multirow[t]{2}{*}{ Lox 14} & Forward primer & AACAAGGGATGGGACCTGAG \\
\hline & Reverse primer & ACCTTCTCCACCCAGTAAGC \\
\hline \multirow[t]{2}{*}{ Cyr61 } & Forward primer & TCACCCTTCTCCACTTGACC \\
\hline & Reverse primer & CTGCAGTCCTCGTTGAGTTG \\
\hline \multirow[t]{2}{*}{ Sesn3 } & Forward primer & CTTTCCCACATGGCTGTCTG \\
\hline & Reverse primer & TTGTGGTGTGAGCTTGTGTG \\
\hline \multirow[t]{2}{*}{ Prg4 } & Forward primer & AAAGAGACACGGAGTGCAGA \\
\hline & Reverse primer & GTGGTAGTGGGAGCTGAGTT \\
\hline \multirow[t]{2}{*}{ Flnb } & Forward primer & ATGCATCCCACAGTCCTTCA \\
\hline & Reverse primer & CCATGACCCTCACTTCCAGT \\
\hline \multirow[t]{2}{*}{ Fzd7 } & Forward primer & CCTACCTAGTGGACATGCGT \\
\hline & Reverse primer & CACTGCCACCATGAAGTAGC \\
\hline \multirow[t]{2}{*}{ Bmp7 } & Forward primer & GAAGCGTGCAAGGCATTAGA \\
\hline & Reverse primer & TTCCAGAGGCAGTGTGTAGG \\
\hline \multirow[t]{2}{*}{ Rps24 } & Forward primer & AAACCGTCTGCTTCAGAGGA \\
\hline & Reverse primer & CAAAGCCAGTTGTCTTGCCT \\
\hline \multirow[t]{2}{*}{ Fabp4 } & Forward primer & ATGTGCAGAAGTGGGATGGA \\
\hline & Reverse primer & GTCACGCCTITCATGACACA \\
\hline \multirow[t]{2}{*}{ B2m } & Forward primer & GGACAAGGAGCCTTCTGAGT \\
\hline & Reverse primer & CAACAGAAGGGCAGAAGACG \\
\hline \multirow[t]{2}{*}{ Ogn } & Forward primer & GACTGTGCATCCTACGCTTC \\
\hline & Reverse primer & AGTCCAGCTGAGTTTGTGGT \\
\hline \multirow[t]{2}{*}{ Rbp7 } & Forward primer & TTCAGGCTTTAGCTGCCAAC \\
\hline & Reverse primer & CCTCGAAGTTATCGCTGCTG \\
\hline \multirow[t]{2}{*}{ Lyz1 } & Forward primer & AGAATCACTGCCATGTTGCC \\
\hline & Reverse primer & TTCTTCCAGCCCTGCCAATA \\
\hline \multirow[t]{2}{*}{ Adipoq } & Forward primer & GACAAGGCCGTTCTCTTCAC \\
\hline & Reverse primer & CCCATACACTTGGAGCCAGA \\
\hline \multirow[t]{2}{*}{ Cebpd } & Forward primer & AACGACCGATACCTCAGACC \\
\hline & Reverse primer & TAGCTTCTCTCGCAGTCCAG \\
\hline \multirow[t]{2}{*}{ Thrsp } & Forward primer & AAGGCAGTGAGGCTGAGAAT \\
\hline & Reverse primer & GTGGAACTGGGCTTCTAGGT \\
\hline \multirow[t]{2}{*}{ Dnajc15 } & Forward primer & AGATGAGCTACGGAGACTGC \\
\hline & Reverse primer & GAAGGGACGGACTATGCTGA \\
\hline \multirow[t]{2}{*}{ Col2a1 } & Forward primer & CAAGAAGGCCTTGCTCATCC \\
\hline & Reverse primer & CAGTGTACGTGAACCTGCTG \\
\hline \multirow[t]{2}{*}{ Hapln1 } & Forward primer & GACAGCTACACTCCGGATCA \\
\hline & Reverse primer & AGCCAAATGCTGTAGGGTCT \\
\hline
\end{tabular}


Table 6 List of genes and their specific primer sequences for qRT-PCR validation (Continued)

\begin{tabular}{lll}
\hline Gene name & Primer & Sequence \\
\hline Col9a1 & Forward primer & CCAGCACATCAAGCAGGTT \\
& Reverse primer & CCTCCCAGGAAGACCAGAAG \\
Col11a1 & Forward primer & GCAGGGAAGAAGGTGCAAA \\
& Reverse primer & CTCCAGGAAGGCCTCTTCA \\
Sox9 & Forward primer & GAAGAATGGGCAAGCAGAGG \\
& Reverse primer & GCCTTGAAGATGGCGTTAGG \\
Sox6 & Forward primer & TTGGGCAAAGGACAAAGG \\
& Reverse primer & CGGGCCTGCTCTTCATAGTA \\
Sox5 & Forward primer & ACAGCACCTGGAGAAGTACC \\
& Reverse primer & ATGCGCAGTTCTTCCCATC \\
Comp & Forward primer & CAGCTCAAGGCTGTCAAGTC \\
& Reverse primer & CTTCCAGCCCACATTCGAG \\
Fgfr3 & Forward primer & TGCTGGTGACTGAGGACAAT \\
& Reverse primer & GAGGACACCAAAGGACCAGA \\
Matn1 & Forward primer & GGATGAGCACGTGGATACG \\
& Reverse primer & Forward primer \\
Gapdh & Reverse primer & CAAGGCTGAGAATGGGAAGC \\
& & GAAGACGCCAGTAGACTCCA \\
\hline
\end{tabular}

homeostasis by controlling multiple signaling pathways involved in cartilage growth and development.

Among the significantly upregulated DEGs, 17 DEGs involved in cartilage growth and regeneration were identified, including Ctgf, Fn1, Acan, Loxl4, Cyr61, Sesn3, Prg4, Flnb, Fzd7, Bmp7, Bmp6, Golgb1, Pi15, Klf9, Gli2, Efna5, and Trps1. Ctgf, also known as cellular communication network factor 2 (Cnn2), is an essential growth factor that plays pivotal roles in regulating cartilage homeostasis, development, and regeneration [32]. Fn1 is a highly expressed extracellular matrix glycoprotein during cartilage repair and regeneration [33]. Acan, a critical proteoglycan component for cartilage structure, is indispensable not only for the formation of cartilage in development but also for the maintenance of cartilage after maturation [34]. Loxl4 is a family member of lysyl oxidases that play crucial roles in the maintenance of cartilage function and cartilage regeneration [35]. Cyr61, also known as cellular communication network factor 1 (Cnn1), has the capacity to promote cartilage regeneration by facilitating chondrocyte cloning in osteoarthritic cartilage [36]. Sesn3, a member of the sestrin family, is significantly downregulated in aging and osteoarthritic cartilage [37]. Prg4, also known as lubricin, is defined as a chondroprotective glycoprotein that is essential for cartilage homeostasis and repair [38]. Flnb, a type of cytoskeletal proteins, is universally expressed in the growth plate of cartilage and cartilaginous condensation of developing vertebrae, and absence of Flnb causes progressive amalgamation and malformation in the growth plate of postnatal vertebrae [39]. Fzd7, a receptor of Wnt signaling pathway, is required for column formation and regeneration of cartilage growth plate [40]. Bmp7, also known as osteogenic protein-1 (Op-1), serve as a cartilage anabolic factor that has the ability to induce matrix synthesis and promote repair in various models of articular cartilage degradation [41]. Bmp6 is a growth factor responsible for the maintenance of joint integrity and serves as a potential therapeutic molecule for cartilage repair [42]. Golgb1, also known as giantin, plays crucial roles in regulating chondrogenesis and the development of cartilage growth plate [43]. Pi15 is a key protease inhibitor involved in cartilage anabolism during cartilage repair [44]. Klf9, a family member of the $\mathrm{C}_{2} \mathrm{H}_{2}$ zinc finger transcription factors, is highly expressed in the vertebrae cartilage primordia [45]. Gli2 is also a $\mathrm{C}_{2} \mathrm{H}_{2}$ zinc finger transcription factors widely expressed in most types of chondrocytes, but at a lower level in hypertrophic chondrocytes [46]. Efna5, a cell surface GPI-bound ligand for Eph receptors, is highly expressed in normal cartilage [47]. Trps1 is predominantly expressed in the joints and limb growth plate cartilages, and acts as a key transcription factor involved in cartilage formation [48]. These findings suggest that DAE potentially facilitate $\mathrm{XC}$ growth and regeneration by controlling multiple functional genes involved in cartilage growth and regeneration.

Among the significantly upregulated DEGs, 30 DEGs involved in inflammation were identified, including Rps24, Fabp4, B2m, Ogn, Rbp7, Lyz1, Adipoq, Cebpd, 


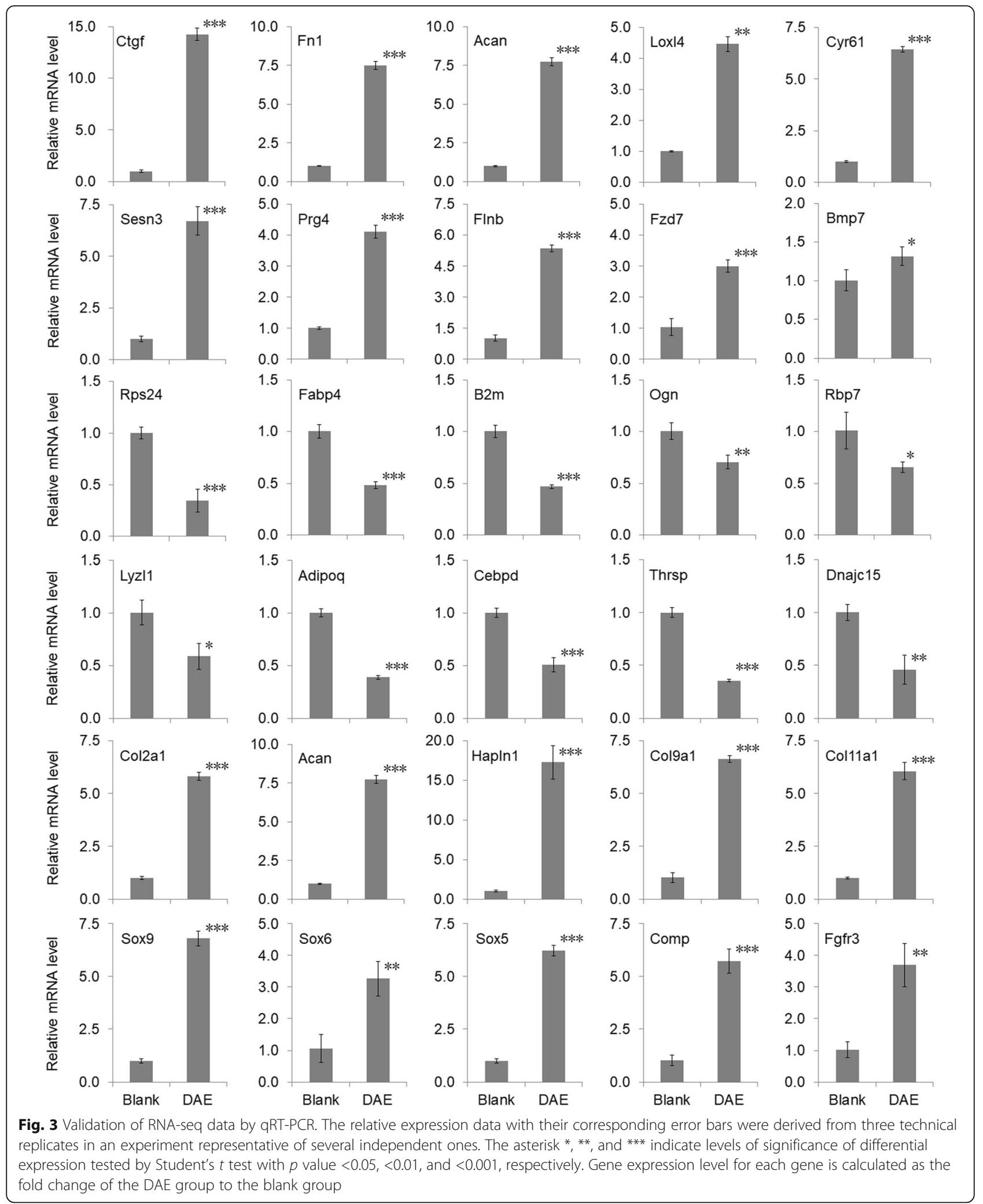

Thrsp, Dnajc15, Cebpb, Cd36, Retn, Col4a1, Agt, Macrod1, Ifi27l2b, Nfkbia, C1qc, Cebpa, Cxcl12, Ccl21a, Cxcl13, Snx2, Ctss, C1qb, Mmp23, Spon2, Lrg1, and
Pxdn. Among these DEGs, Fabp4, Macrod1, Ifi27l2b, $\mathrm{C} 1 \mathrm{qc}, \mathrm{C} 1 \mathrm{qb}$, and $\mathrm{Mmp} 23$ are involved in the process of inflammation [49-54]. B2m, a component of MHC class 
I molecules for monitoring inflammatory reaction, is highly expressed in osteoarthritis (OA) patients than controls, regardless of OA stage [55]. Lyz1, Dnajc15, Nfkbia, Cxcl12, Ccl21a, and Cxcl13 are considered to be arthritis-associated gene [56-61]. Cebpd is expressed at a relatively low level under normal physiological conditions and is upregulated by a variety of inflammatory stimuli, such as arthritis [62]. Furthermore, Rps24, Ogn, Rbp7, Adipoq, Thrsp, Cebpb, Cd36, Retn, Col4a1, Agt, Cebpa, Snx2, Ctss, Spon2, Lrg1, and Pxdn were also highly expressed in OA models compared to non-OAs [63-78]. These findings suggest that DAE potentially prevent $\mathrm{XC}$ from the risk of inflammation by supressing multiple functional genes involved in the process of inflammation. In consistent with the above results, the expression levels of a series of chondroprogenitor and proliferative chondrocyte markers, including Col2a1, Acan, Hapln1, Col9a1, Col11a1, Sox9, Sox6, Sox5, Comp, Fgfr3, Matn1, Sdc3, and Ptch1 were slightly increased under DAE treatment. Taken together, our findings suggest that DAE might serve as a complementary therapeutic regent for cartilage growth and regeneration.

\section{Conclusion}

In summary, the present study demonstrated that DAE significantly increased the expression levels of DEGs involved in cartilage growth and regeneration, but decreased the expression levels of DEGs involved in inflammation, and mildly increased the expression levels of DEGs involved in chondrogenesis and chondrocyte proliferation. Thus, our findings suggest that DAE might serve as a complementary therapeutic regent for cartilage growth and regeneration to treat cartilage degenerative disease, such as osteoarthritis.

\section{Abbreviations}

XC: Xiphoid cartilage; DAE: Deer antler extract; RNA-seq: RNA sequencing; qRT-PCR: Quantitative real-time PCR; SPF: Specific pathogen-free; SD: Sprague-Dawley; DEGs: Differentially expressed genes; Gapdh: Glyceraldehyde 3-phosphate dehydrogenase; KEGG: Kyoto Encyclopedia of Genes and Genomes; SRA: Sequence Read Archive; NCBI: National Center for Biotechnology Information; GO: Gene ontology; NR: Non-redundant
}

\section{Acknowledgements}

Not applicable

\section{Authors' contributions}

B.Y., X.L., and M.G. conceived and designed the work; B.Y. and X.L. helped to coordinate support and funding; M.G., D.P., and M.Z. performed the experiments; M.G. and D.P. analyzed the data and wrote the original draft; B.Y. and X.L. reviewed and revised the manuscript. All authors read and approved the final version of manuscript.

\section{Funding}

This work was supported by the National Key Research and Development Program of China (Grant No. 2018YFC1706605), the National Natural Science Foundation of China (Grant No. 81973887 and 81702136), and the TCM Clinical Research Center for Bone diseases of Jilin Province (Grant No. 20180623048TC). The funding bodies provided financial support, and the awardees performed the research. The founding sponsor had no role in the design of the study, the collection, analysis, and interpretation of data and in writing the manuscript.

\section{Availability of data and materials}

The datasets used and/or analyzed during the current study are available from the corresponding author on reasonable request.

\section{Declarations}

\section{Ethics approval and consent to participate}

All procedures were performed in accordance with the guidelines of the Institutional Animal Ethics Committee of Changchun University of Chinese Medicine (No. ccucm-2017-0015). The animal protocol was approved by the Institutional Animal Care and Use Committee of Changchun University of Chinese Medicine. This study was carried out in compliance with the ARRIVE guidelines (http://www.nc3rs.org.uk/page.asp?id=1357).

\section{Consent for publication}

Not applicable.

\section{Competing interests}

The authors declare that they have no competing interests.

\section{Author details}

${ }^{1}$ College of Traditional Chinese Medicine, Changchun University of Chinese Medicine, Changchun 130117, China. ${ }^{2}$ Jilin Ginseng Academy, Changchun University of Chinese Medicine, Changchun 130117, China. ${ }^{3}$ Innovation Practice Center, Changchun University of Chinese Medicine, Changchun, Jilin 130117, China.

Received: 12 January 2021 Accepted: 10 March 2021

Published online: 22 March 2021

\section{References}

1. Mashriqi F, D'Antoni AV, Tubbs RS. Xiphoid process variations: a review with an extremely unusual case report. Cureus. 2017;9(8):e1613. https://doi.org/1 0.7759 /cureus. 1613

2. Xie YZ, Wang BJ, Yun JS, Chung GH, Ma ZB, Li XJ, Kim IS, Chai OH, Han EH, Kim HT, Song CH. Morphology of the human xiphoid process: dissection. and radiography of cadavers and MDCT of patients. Surg Radiol Anat. 2014; 36(3):209-17. https://doi.org/10.1007/s00276-013-1163-8.

3. Simpson JK, Hawken E. Xiphodynia: a diagnostic conundrum. Chiropr Osteopat. 2007;15(1):13. https://doi.org/10.1186/1746-1340-15-13.

4. Hogerzeil DP, Hartholt KA, de Vries MR. Xiphoidectomy: a surgical intervention for an underdocumented disorder. Case Rep Surg. 2016;2016: 9306262.

5. Oldershaw RA. Cell sources for the regeneration of articular cartilage: the past, the horizon and the future. Int J Exp Pathol. 2012;93(6):389-400. https://doi.org/10.1111/j.1365-2613.2012.00837.x.

6. Price JS, Allen S, Faucheux C, Althnaian T, Mount JG. Deer antlers: a zoological curiosity or the key to understanding organ regeneration in mammals? J Anat. 2005;207(5):603-18. https://doi.org/10.1111/j.1469-7580.2 005.00478.x.

7. Price J, Allen S. Exploring the mechanisms regulating regeneration of deer antlers. Philos Trans R Soc Lond Ser B Biol Sci. 2004;359(1445):809-22. https://doi.org/10.1098/rstb.2004.1471.

8. Wang D, Berg D, Ba H, Sun H, Wang Z, Li C. Deer antler stem cells are a novel type of cells that sustain full regeneration of a mammalian organdeer antler. Cell Death Dis. 2019;10(6):443. https://doi.org/10.1038/s41419-01 9-1686-y.

9. Kierdorf U, Li C, Price JS. Improbable appendages: deer antler renewal as a unique case of mammalian regeneration. Semin Cell Dev Biol. 2009;20(5): 535-42. https://doi.org/10.1016/j.semcdb.2008.11.011.

10. Chen J, Yang Y, Abbasi S, Hajinezhad D, Kontulainen S, Honaramooz A. The effects of elk velvet antler dietary supplementation on physical growth and bone development in growing rats. Evid Based Complement Alternat Med. 2015;2015:819520

11. Yao B, Zhang M, Leng X, Liu M, Liu Y, Hu Y, Zhao D, Zhao Y. Antler extracts stimulate chondrocyte proliferation and possess potent anti-oxidative, anti- 
inflammatory, and immune-modulatory properties. In Vitro Cell Dev Biol Anim. 2018;54(6):439-48. https://doi.org/10.1007/s11626-018-0266-2.

12. Yao $B$, Zhang $M$, Leng $X$, Zhao D. Proteomic analysis of the effects of antler extract on chondrocyte proliferation, differentiation and apoptosis. Mol Biol Rep. 2019;46(2):1635-48. https://doi.org/10.1007/s11033-019-04612-1.

13. Yao B, Gao H, Liu J, Zhang M, Leng X, Zhao D. Identification of potential therapeutic targets of deer antler extract on bone regulation based on serum proteomic analysis. Mol Biol Rep. 2019;46(5):4861-72. https://doi. org/10.1007/s11033-019-04934-0

14. Reagan-Shaw S, Nihal M, Ahmad N. Dose translation from animal to human studies revisited. FASEB J. 2008;22(3):659-61. https://doi.org/10.1096/fj.079574LSF.

15. Kim D, Langmead B, Salzberg SL. HISAT: a fast spliced aligner with low memory requirements. Nat Methods. 2015;12(4):357-60. https://doi.org/10.1 038/nmeth.3317.

16. Trapnell C, Williams BA, Pertea G, Mortazavi A, Kwan G, van Baren MJ, Salzberg SL, Wold BJ, Pachter L. Transcript assembly and quantification by RNA-Seq reveals unannotated transcripts and isoform switching during cell differentiation. Nat Biotechnol. 2010;28(5):511-5. https://doi.org/10.1038/ nbt.1621.

17. Wang L, Feng Z, Wang X, Wang X, Zhang X. DEGseq: an R package for identifying differentially expressed genes from RNA-seq data. Bioinformatics. 2010;26(1):136-8. https://doi.org/10.1093/bioinformatics/btp612

18. Yao B, Wang C, Zhou Z, Zhang M, Zhao D, Bai X, Leng X. Comparative transcriptome analysis of the main beam and brow tine of sika deer antler provides insights into the molecular control of rapid antler growth. Cell Mol Biol Lett. 2020;25(1):42. https://doi.org/10.1186/s11658-020-00234-9.

19. Schmittgen TD, Livak KJ. Analyzing real-time PCR data by the comparative $C$ (T) method. Nat Protoc. 2008;3(6):1101-8. https://doi.org/10.1038/nprot.2008.73.

20. Jiang S, Guo W, Tian G, Luo X, Peng L, Liu S, Sui X, Guo Q, Li X. Clinical application status of articular cartilage regeneration techniques: tissueengineered cartilage brings new hope. Stem Cells Int. 2020;2020:5690252.

21. Kloppenburg M, Berenbaum F. Osteoarthritis year in review 2019: epidemiology and therapy. Osteoarthr Cartil. 2020;28(3):242-8. https://doi. org/10.1016/j.joca.2020.01.002.

22. Nam S, Cho W, Cho H, Lee J, Lee E, Son Y. Xiphoid process-derived chondrocytes: a novel cell source for elastic cartilage regeneration. Stem Cells Transl Med. 2014;3(11):1381-91. https://doi.org/10.5966/sctm.2014-0070.

23. Huang Y, Zhou J, Hakamivala A, Wu J, Hong Y, Borrelli J, Tang L. An optical probe for detecting chondrocyte apoptosis in response to mechanical injury. Sci Rep. 2017;7(1):10906. https://doi.org/10.1038/s41598-017-10653-y.

24. Wang Y, Huang YC, Gertzman AA, Xie L, Nizkorodov A, Hyzy SL, Truncale K, Guldberg RE, Schwartz Z, Boyan BD. Endogenous regeneration of criticalsize chondral defects in immunocompromised rat xiphoid cartilage using decellularized human bone matrix scaffolds. Tissue Eng Part A. 2012;18(2122):2332-42. https://doi.org/10.1089/ten.tea.2011.0688.

25. Davis CG, Eisner E, McGlynn M, Shelton JM, Richardson J, Borrelli J Jr, Chen CC. Posttraumatic chondrocyte apoptosis in the murine xiphoid. Cartilage. 2013;4(4):345-53. https://doi.org/10.1177/1947603513489830.

26. Zihni C, Mills C, Matter K, Balda MS. Tight junctions: from simple barriers to multifunctional molecular gates. Nat Rev Mol Cell Biol. 2016;17(9):564-80. https://doi.org/10.1038/nrm.2016.80

27. Vasheghani F, Zhang Y, Li YH, Blati M, Fahmi H, Lussier B, Roughley P, Lagares D, Endisha H, Saffar B, Lajeunesse D, Marshall WK, Rampersaud YR, Mahomed NN, Gandhi R, Pelletier JP, Martel-Pelletier J, Kapoor M. PPARy deficiency results in severe, accelerated osteoarthritis associated with aberrant mTOR signalling in the articular cartilage. Ann Rheum Dis. 2015; 74(3):569-78. https://doi.org/10.1136/annrheumdis-2014-205743.

28. García-Alvarez F, Castiella T, Guallar E, Grasa JM, Gómez-Barrena E, Laclériga A. Influence of platelet time activation on articular cartilage growth in the rabbit knee: preliminary study. Knee. 2008;15(4):314-7. https://doi.org/10.101 6/j.knee.2008.02.006

29. Jang KW, Buckwalter JA, Martin JA. Inhibition of cell-matrix adhesions prevents cartilage chondrocyte death following impact injury. J Orthop Res. 2014;32(3):448-54. https://doi.org/10.1002/jor.22523.

30. Wang Q, Rozelle AL, Lepus CM, Scanzello CR, Song JJ, Larsen DM, Crish JF, Bebek G, Ritter SY, Lindstrom TM, Hwang I, Wong HH, Punzi L, Encarnacion A, Shamloo M, Goodman SB, Wyss-Coray T, Goldring SR, Banda NK, Thurman JM, Gobezie R, Crow MK, Holers VM, Lee DM, Robinson WH. Identification of a central role for complement in osteoarthritis. Nat Med. 2011;17(12):1674-9. https://doi.org/10.1038/nm.2543.
31. Zhou S, Lu W, Chen L, Ge Q, Chen D, Xu Z, Shi D, Dai J, Li J, Ju H, Cao Y, Qin J, Chen $\mathrm{S}$, Teng $\mathrm{H}$, Jiang Q. AMPK deficiency in chondrocytes accelerated the progression of instability-induced and ageing-associated osteoarthritis in adult mice. Sci Rep. 2017;7(1):43245. https://doi.org/10.1038/srep43245.

32. Kubota S, Takigawa M. The role of CCN2 in cartilage and bone development. J Cell Commun Signal. 2011;5(3):209-17. https://doi.org/10.1 007/s12079-011-0123-5.

33. Imabuchi R, Ohmiya Y, Kwon HJ, Onodera S, Kitamura N, Kurokawa T, Gong JP, Yasuda K. Gene expression profile of the cartilage tissue spontaneously regenerated in vivo by using a novel double-network gel: comparisons with the normal articular cartilage. BMC Musculoskelet Disord. 2011;12(1):213. https://doi.org/10.1186/1471-2474-12-213.

34. Hu G, Codina M, Fisher S. Multiple enhancers associated with ACAN suggest highly redundant transcriptional regulation in cartilage. Matrix Biol. 2012; 31(6):328-37. https://doi.org/10.1016/j.matbio.2012.06.001.

35. Lin W, Xu L, Li G. Molecular insights into lysyl oxidases in cartilage regeneration and rejuvenation. Front Bioeng Biotechnol. 2020;8:359. https:// doi.org/10.3389/fbioe.2020.00359

36. Chijiiwa M, Mochizuki S, Kimura T, Abe H, Tanaka Y, Fujii Y, Shimizu H, Enomoto H, Toyama Y, Okada Y. CCN1 (Cyr61) is overexpressed in human osteoarthritic cartilage and inhibits ADAMTS-4 (Aggrecanase 1) activity. Arthritis Rheum. 2015;67(6):1557-67. https://doi.org/10.1002/art.39078.

37. Shen T, Alvarez-Garcia O, Li Y, Olmer M, Lotz MK. Suppression of Sestrins in aging and osteoarthritic cartilage: dysfunction of an important stress defense mechanism. Osteoarthr Cartil. 2017;25(2):287-96. https://doi.org/1 0.1016/j.joca.2016.09.017

38. Lee $Y$, Choi J, Hwang NS. Regulation of lubricin for functional cartilage tissue regeneration: a review. Biomater Res. 2018;22(1):9. https://doi.org/1 0.1186/s40824-018-0118-x.

39. Zieba J, Forlenza KN, Khatra JS, Sarukhanov A, Duran I, Rigueur D, Lyons KM, Cohn DH, Merrill AE, Krakow D. TGF $\beta$ and BMP dependent cell fate changes due to loss of filamin $B$ produces disc degeneration and progressive vertebral fusions. PLoS Genet. 2016;12(3):e1005936. https://doi.org/10.1371/ journal.pgen.1005936.

40. Randall RM, Shao YY, Wang L, Ballock RT. Activation of Wht Planar Cell Polarity (PCP) signaling promotes growth plate column formation in vitro. J Orthop Res. 2012;30(12):1906-14. https://doi.org/10.1002/jor.22152.

41. Chubinskaya S, Hurtig M, Rueger DC. OP-1/BMP-7 in cartilage repair. Int Orthop. 2007;31(6):773-81. https://doi.org/10.1007/s00264-007-0423-9.

42. Bobacz K, Gruber R, Soleiman A, Erlacher L, Smolen JS, Graninger WB. Expression of bone morphogenetic protein 6 in healthy and osteoarthritic human articular chondrocytes and stimulation of matrix synthesis in vitro. Arthritis Rheum. 2003;48(9):2501-8. https://doi.org/10.1002/art.11248.

43. Stevenson NL, Bergen DJM, Skinner REH, Kague E, Martin-Silverstone E, Robson Brown KA, Hammond CL, Stephens DJ. Giantin-knockout models reveal a feedback loop between Golgi function and glycosyltransferase expression. J Cell Sci. 2017;130(24):4132-43. https:// doi.org/10.1242/jcs.212308.

44. Robinson JL, Soria P, Xu M, Vrana M, Luchetti J, Lu HH, Chen J, Wadhwa S. Estrogen promotes mandibular condylar fibrocartilage chondrogenesis and inhibits degeneration via estrogen receptor alpha in female mice. Sci Rep. 2018;8(1):8527. https://doi.org/10.1038/s41598-018-26937-w.

45. Martin KM, Metcalfe JC, Kemp PR. Expression of Klf9 and KIf13 in mouse development. Mech Dev. 2001;103(1-2):149-51. https://doi.org/10.1016/S092 5-4773(01)00343-4.

46. Mau E, Whetstone H, Yu C, Hopyan S, Wunder JS, Alman BA. PTHrP regulates growth plate chondrocyte differentiation and proliferation in a Gli3 dependent manner utilizing hedgehog ligand dependent and independent mechanisms. Dev Biol. 2007;305(1):28-39. https://doi.org/10.1 016/j.ydbio.2007.01.031.

47. Kalinski T, Röpke A, Sel S, Kouznetsova I, Röpke M, Roessner A. Down-regulation of ephrin-A5, a gene product of normal cartilage, in chondrosarcoma. Hum Pathol. 2009:40(12):1679-85. https://doi.org/10.1016/j.humpath.2009.03.024.

48. Itoh S, Kanno S, Gai Z, Suemoto H, Kawakatsu M, Tanishima H, Morimoto Y, Nishioka K, Hatamura I, Yoshida M, Muragaki Y. Trps1 plays a pivotal role downstream of Gdf5 signaling in promoting chondrogenesis and apoptosis of ATDC5 cells. Genes Cells. 2008;13(4):355-63. https://doi.org/10.1111/j.13 65-2443.2008.01170.x.

49. Hardaway AL, Podgorski I. IL-1 $\beta$, RAGE and FABP4: targeting the dynamic trio in metabolic inflammation and related pathologies. Future Med Chem. 2013;5(10):1089-108. https://doi.org/10.4155/fmc.13.90. 
50. Zang L, Hong Q, Yang G, Gu W, Wang A, Dou J, Mu Y, Wu D, Lyu Z. MACROD1/LRP16 enhances LPS-stimulated inflammatory responses by upregulating a Rac1-dependent pathway in adipocytes. Cell Physiol Biochem. 2018;51(6):2591-603. https://doi.org/10.1159/000495931.

51. Lucas TM, Richner JM, Diamond MS. The interferon-stimulated gene Ifi27/2a restricts West Nile virus infection and pathogenesis in a cell-type- and regionspecific manner. J Virol. 2015;90(5):2600-15. https://doi.org/10.1128/JVI.02463-15.

52. Chang JC, Sebastian A, Murugesh DK, Hatsell S, Economides AN, Christiansen BA, Loots GG. Global molecular changes in a tibial compression induced ACL rupture model of post-traumatic osteoarthritis. J Orthop Res. 2017;35(3):474-85. https://doi.org/10.1002/jor.23263.

53. Li C, Zheng Z. Identification of novel targets of knee osteoarthritis shared by cartilage and synovial tissue. Int J Mol Sci. 2020;21(17):6033. https://doi.org/1 0.3390/ijms21176033.

54. Fonseca-Camarillo G, Furuzawa-Carballeda J, Martínez-Benitez B, BarretoZuñiga R, Yamamoto-Furusho JK. Increased expression of extracellular matrix metalloproteinase inducer (EMMPRIN) and MMP10, MMP23 in inflammatory bowel disease: cross-sectional study. Scand J Immunol. 2020;27:e12962.

55. Melikoglu MA, Yildirim K, Senel K. Relationship between radiographic grading of osteoarthritis and serum beta-2 microglobulin. Ir J Med Sci. 2009; 178(2):151-4. https://doi.org/10.1007/s11845-008-0219-y.

56. Sebastian A, Murugesh DK, Mendez ME, Hum NR, Rios-Arce ND, McCool JL, Christiansen BA, Loots GG. Global gene expression analysis identifies agerelated differences in knee joint transcriptome during the development of post-traumatic osteoarthritis in mice. Int J Mol Sci. 2020;21(1):364. https:// doi.org/10.3390/ijms21010364.

57. Zhang D, Li Z, Zhang R, Yang X, Zhang D, Li Q, Wang C, Yang X, Xiong Y. Identification of differentially expressed and methylated genes associated with rheumatoid arthritis based on network. Autoimmunity. 2020;53(6):30313. https://doi.org/10.1080/08916934.2020.1786069.

58. Cai P, Jiang T, Li B, Qin X, Lu Z, Le Y, Shen C, Yang Y, Zheng L, Zhao J. Comparison of rheumatoid arthritis (RA) and osteoarthritis (OA) based on microarray profiles of human joint fibroblast-like synoviocytes. Cell Biochem Funct. 2019;37(1):31-41. https://doi.org/10.1002/cbf.3370.

59. Peng L, Zhu N, Mao J, Huang L, Yang Y, Zhou Z, Wang L, Wu B. Expression levels of CXCR4 and CXCL12 in patients with rheumatoid arthritis and its correlation with disease activity. Exp Ther Med. 2020;20(3):1925-34. https:// doi.org/10.3892/etm.2020.8950.

60. Pickens SR, Chamberlain ND, Volin MV, Pope RM, Mandelin AM 2nd, Shahrara S. Characterization of CCL19 and CCL21 in rheumatoid arthritis. Arthritis Rheum. 2011;63(4):914-22. https://doi.org/10.1002/art.30232.

61. Meeuwisse CM, van der Linden MP, Rullmann TA, Allaart CF, Nelissen R, Huizinga TW, Garritsen A, Toes RE, van Schaik R, van der Helm-van Mil AH. Identification of CXCL13 as a marker for rheumatoid arthritis outcome using an in silico model of the rheumatic joint. Arthritis Rheum. 2011;63(5):126573. https://doi.org/10.1002/art.30273.

62. Chang LH, Huang HS, Wu PT, Jou IM, Pan MH, Chang WC, Wang DD, Wang $J M$. Role of macrophage CCAAT/enhancer binding protein delta in the pathogenesis of rheumatoid arthritis in collagen-induced arthritic mice. PLoS One. 2012;7(9):e45378. https://doi.org/10.1371/journal.pone.0045378.

63. Mi B, Liu G, Zhou W, Lv H, Liu Y, Liu J. Identification of genes and pathways in the synovia of women with osteoarthritis by bioinformatics analysis. Mol Med Rep. 2018;17(3):4467-73. https://doi.org/10.3892/mmr.2018.8429.

64. Aki T, Hashimoto K, Ogasawara M, Itoi E. A whole-genome transcriptome analysis of articular chondrocytes in secondary osteoarthritis of the hip. PLoS One. 2018;13(6):e0199734. https://doi.org/10.1371/journal.pone.0199734.

65. Gelse K, Ekici AB, Cipa F, Swoboda B, Carl HD, Olk A, Hennig FF, Klinger P. Molecular differentiation between osteophytic and articular cartilage--clues for a transient and permanent chondrocyte phenotype. Osteoarthr Cartil. 2012;20(2):162-71. https://doi.org/10.1016/j.joca.2011.12.004.

66. Shang H, Hao Y, Hu W, Hu X, Jin Q. Association between ADIPOQ gene variants and knee osteoarthritis in a Chinese population. Biosci Rep. 2019; 39(3):BSR20182104. https://doi.org/10.1042/BSR20182104.

67. Gandhi R, Takahashi M, Virtanen C, Syed K, Davey JR, Mahomed NN. Microarray analysis of the infrapatellar fat pad in knee osteoarthritis: relationship with joint inflammation. J Rheumatol. 2011;38(9):1966-72. https://doi.org/10.3899/jrheum.101302.

68. Hirata M, Kugimiya F, Fukai A, Saito T, Yano F, Ikeda T, Mabuchi A, Sapkota BR, Akune T, Nishida N, Yoshimura N, Nakagawa T, Tokunaga K, Nakamura K, Chung UI, Kawaguchi H. C/EBP $\beta$ and RUNX2 cooperate to degrade cartilage with MMP-13 as the target and HIF-2a as the inducer in chondrocytes. Hum Mol Genet. 2012;21(5):1111-23. https://doi.org/10.1093/hmg/ddr540.

69. Cecil DL, Appleton CT, Polewski MD, Mort JS, Schmidt AM, Bendele A, Beier F, Terkeltaub R. The pattern recognition receptor CD36 is a chondrocyte hypertrophy marker associated with suppression of catabolic responses and promotion of repair responses to inflammatory stimuli. J Immunol. 2009; 182(8):5024-31. https://doi.org/10.4049/jimmunol.0803603.

70. Naqvi SKB, Murtaza I, Javed Q. Role of resistin genetic variations in knee osteoarthritis pathogenesis, a cross sectional study. Mol Biol Rep. 2019;46(3): 2657-63. https://doi.org/10.1007/s11033-019-04673-2.

71. Li HZ, Lu HD. Transcriptome analyses identify key genes and potential mechanisms in a rat model of osteoarthritis. J Orthop Surg Res. 2018;13(1): 319. https://doi.org/10.1186/s13018-018-1019-3.

72. Li M, Zhi L, Zhang Z, Bian W, Qiu Y. Identification of potential target genes associated with the pathogenesis of osteoarthritis using microarray based analysis. Mol Med Rep. 2017;16(3):2799-806. https://doi.org/10.3892/mmr.2 017.6928.

73. Chou CH, Lee MT, Song IW, Lu LS, Shen HC, Lee CH, Wu JY, Chen YT, Kraus VB, Wu CC. Insights into osteoarthritis progression revealed by analyses of both knee tibiofemoral compartments. Osteoarthr Cartil. 2015;23(4):571-80. https://doi.org/10.1016/j.joca.2014.12.020.

74. Yang Y, You X, Cohen JD, Zhou H, He W, Li Z, Xiong Y, Yu T. Sex differences in osteoarthritis pathogenesis: a comprehensive study based on bioinformatics. Med Sci Monit. 2020;26:e923331.

75. Zhou Y, Wang Z, Chen X, Zhang J, Yang L, Liu S, Liu Y. Identification of differentially expressed miRNAs and mRNAs in synovial of osteoarthritis via RNA-sequencing. BMC Med Genet. 2020;21 (1):46. https://doi.org/10.1186/s12 881-020-0978-5.

76. Balakrishnan L, Nirujogi RS, Ahmad S, Bhattacharjee M, Manda SS, Renuse S, Kelkar DS, Subbannayya Y, Raju R, Goel R, Thomas JK, Kaur N, Dhillon M, Tankala SG, Jois R, Vasdev V, Ramachandra Y, Sahasrabuddhe NA, Prasad TK, Mohan S, Gowda H, Shankar S, Pandey A. Proteomic analysis of human osteoarthritis synovial fluid. Clin Proteomics. 2014;11(1):6.

77. Wang $Y, X u$ J, Zhang $X$, Wang $C$, Huang $Y$, Dai K, Zhang $X$. TNF-a-induced LRG1 promotes angiogenesis and mesenchymal stem cell migration in the subchondral bone during osteoarthritis. Cell Death Dis. 2017;8(3):e2715. https://doi.org/10.1038/cddis.2017.129.

78. Sebastian A, Chang JC, Mendez ME, Murugesh DK, Hatsell S, Economides AN, Christiansen BA, Loots GG. Comparative transcriptomics identifies novel genes and pathways involved in post-traumatic osteoarthritis development and progression. Int J Mol Sci. 2018;19(9):2657. https://doi.org/10.3390/ijms1 9092657.

\section{Publisher's Note}

Springer Nature remains neutral with regard to jurisdictional claims in published maps and institutional affiliations.

\section{Ready to submit your research? Choose BMC and benefit from:}

- fast, convenient online submission

- thorough peer review by experienced researchers in your field

- rapid publication on acceptance

- support for research data, including large and complex data types

- gold Open Access which fosters wider collaboration and increased citations

- maximum visibility for your research: over $100 \mathrm{M}$ website views per year

At $\mathrm{BMC}$, research is always in progress.

Learn more biomedcentral.com/submissions 